\title{
Two New Species of the Genus Nesodillo (Isopoda, Oniscidea, Armadillidae) from Philippines
}

\author{
Dae Soo Jeon and Do Heon Kwon* \\ School of Biological Sciences, Inje University, Gimhae 621-749, Korea
}

\begin{abstract}
Two new species of the genus Nesodillo Verhoeff, 1926, N. kimi and N. philippinensis, are described from Philippines. For the shape of frontal shield, Nesodillo kimi resembles N. monticola (Vandel, 1973) from New Guinea, but differs from it in the shape of male pleopod 1 exopod. $N$. philippinensis is distinguished from $N$. kimi by the shape of frontal shield not depressed in the middle of upper border, and of telson with broadly rounded distal margin.
\end{abstract}

Key words: Oniscidea, Armadillidae, Nesodillo, new species, Philippines

\section{INTRODUCTION}

The genus Nesodillo which belongs to the oniscidean family Armadillidae was instituted by Verhoeff (1926) to accommodate nine species from New Caledonia. However Verhoeff (1926) did not choose any species as the type species of the genus. Later, Taiti et al. (1998) designated Nesodillo sarasini Verhoeff, 1926 as the type species of the genus. They mentioned, in the same paper, that they considered the genus Triadillo Vandel, 1973 to be a junior synonym of Nesodillo. Nesodillo is characterized by the semicircular ventral lobes on pereonal epimera 1-3. The genus currently includes about 20 nominal species distributed in Australian and Oriental Regions (Schmalfuss, 2003). Most of the species had been inadequately or erroneously described and partly or not figured. For this reason, it is difficult to clarify Nesodillo-species without reexamination of the holotypes.

Up to now 11 species of armadillids were recorded from Philippines (Dollfus, 1890; Budde-Lund, 1904; Arcangeli, 1927; Vandel, 1974; Schmalfuss, 1987; Jeon and Kwon, 2001). However, this number is assumed to be only a part of armadillidean fauna of Philippines. The genus Nesodillo is recorded for the first time from Philippines and two new species are herein described.

The specimens examined are deposited in the National Institute of Biological Resources, Incheon (NBR) and the School of Biological Sciences, Inje University, Kimhae (IJB).

\footnotetext{
*To whom correspondence should be addressed Tel: 82-55-320-3214, Fax: 82-55-336-7706
}

E-mail: biodhkwo@inje.ac.kr

\section{SYSTEMATIC ACCOUNT}

Genus Nesodillo Verhoeff, 1926

Synonyms: Nesodillo Verhoeff, 1926: 275.

Triadillo Vandel, 1973: 119.

Type species: Nesodillo sarasini Verhoeff, 1926, by subsequent designation (Taiti et al., 1998).

Nesodillo kimi sp. nov. (Figs. 1-3)

Type material. Holotype: ${ }^{\nearrow}$, dimension $9.1 \times 4.1 \mathrm{~mm}$, Luzon I., Quezon, Pagbilao, 29.I.1997, leg. D.H. Kwon, D.S. Jeon and J.A. Kim (NBR). Paratypes: $4 \sigma^{\nearrow}$ ð, 6 우 우, same data as holotype (NBR); $4 \sigma^{\nearrow}$ శ , 6 우 우, same data (IJB).

Description. Maximum dimension of male $9.1 \times 4.1 \mathrm{~mm}$, of female $11.8 \times 5.3 \mathrm{~mm}$. Color in alcohol dark brown with usual pale muscle spots; frontal shield reddish brown; lateral parts of vertex and uropods reddish brown in some specimens; distal half of fifth article of antennal peduncle pigmentless. Dorsum smooth and covered with minute scale-spines. One nodulus lateralis per side on each pereonite; noduli laterales on pereonites 1,4 and 7 much farther from lateral margins than ones on the other pereonites. Eye with 18-20 (rarely 21) ommatidia. Cephalon with frontal shield depressed and bent backwards on vertex in the middle of upper border, clearly protruding over vertex only at sides. Pereonal epimeron 1 not thickened and slightly bent outwards in anterior part; postero-lateral corner subacute and apex rounded; a small lobe on ventral surface. Each of pereonal epimera 2 and 3 quadrangular with a small lobe on ventral surface. Telson hour-glass shaped, with basal part much wider than distal one; distal margin rounded. Antenna with fifth article of 


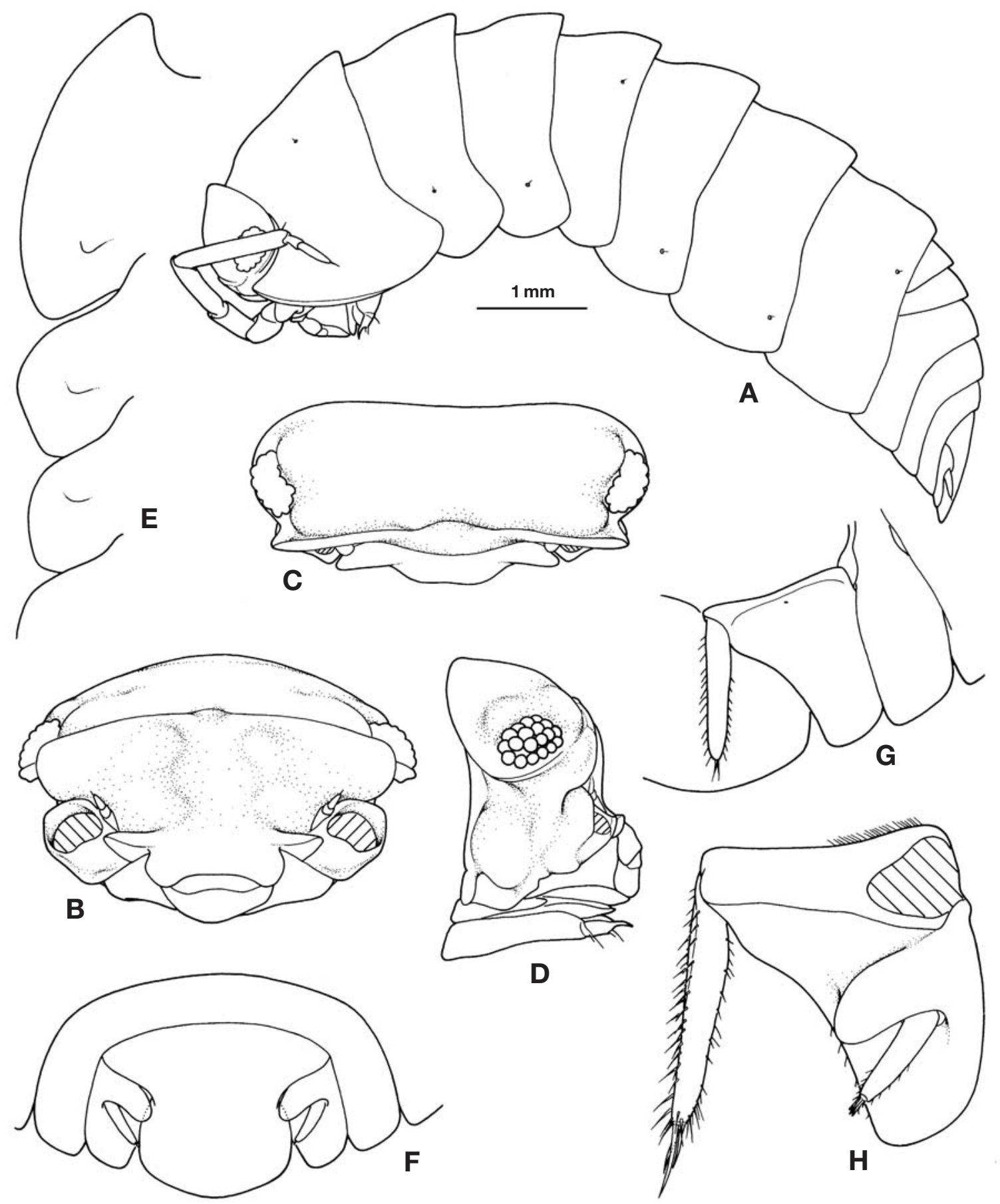

Fig. 1. Nesodillo kimi sp. nov., paratype female: A, habitus, lateral view; B, cephalon, frontal view; C, cephalon, dorsal view; D, cephalon, lateral view; E, pereonal epimera 1-4, ventral view; F, pleonites 4-5, telson and uropods, dorsal view; G, pleonal epimera 4-5, telson and left uropod, ventral view; $H$, right uropod, dorsal view.

peduncle about twice as long as flagellum; distal article of flagellum about three times as long as proximal one. Mandible with molar penicil consisting of numerous plumose setae of increasing length, arising from a common stem; right mandible with 2 and left one with 5 (rarely 6) penicils between molar penicil and lacinia mobilis. Maxillular exopod 


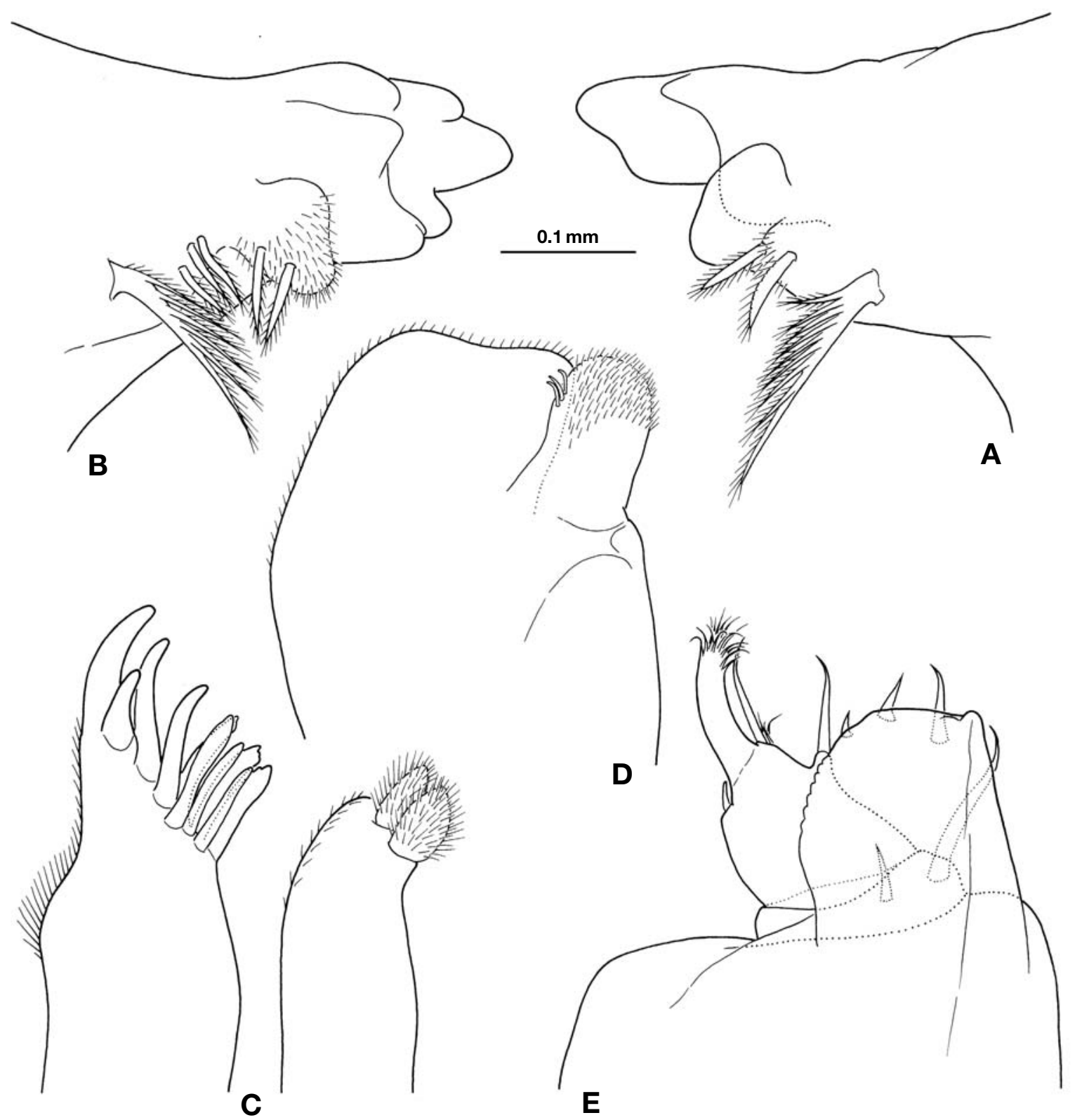

Fig. 2. Nesodillo kimi sp. nov., paratype male: A, right mandible; $B$, left mandible; C, maxillule, caudal view; $D$, maxilla, rostral view; E, maxilliped, rostral view.

with 4 stout outer teeth and 6 slender inner ones; endopod with two short unequal stout penicils. Maxilla two-lobed, with setose inner lobe bearing 3 curved setae stronger than the other ones, near outer margin of rostral surface; outer lobe much larger than inner one, bearing concave distal margin. Maxillipedal endite with 3 stout setae on distal margin; palp reduced, two-segmented with distal segment bearing slender distal part divided from proximal one by indistinct suture line and bearing two long, stout setae on inner margin of proximal part. Pereopod 1 shortest of all; carpus shortest than any carpi of other pereopods, with a setose groove on rostral surface. Pereopods 2-7 similar in shape except for the shape of ischia with distal corners of tergal margins obtuse on pereopods 2-4 and right-angled on 5-7; posterior pereopods progressively longer. Each pleopodal exopod with a polyspiracular covered lung (Taiti et al., 1998). Uropodal protopod trapezoidal, fitting in the gap between pleonal epimeron 5 and telson, with mesial margin slightly concave; 


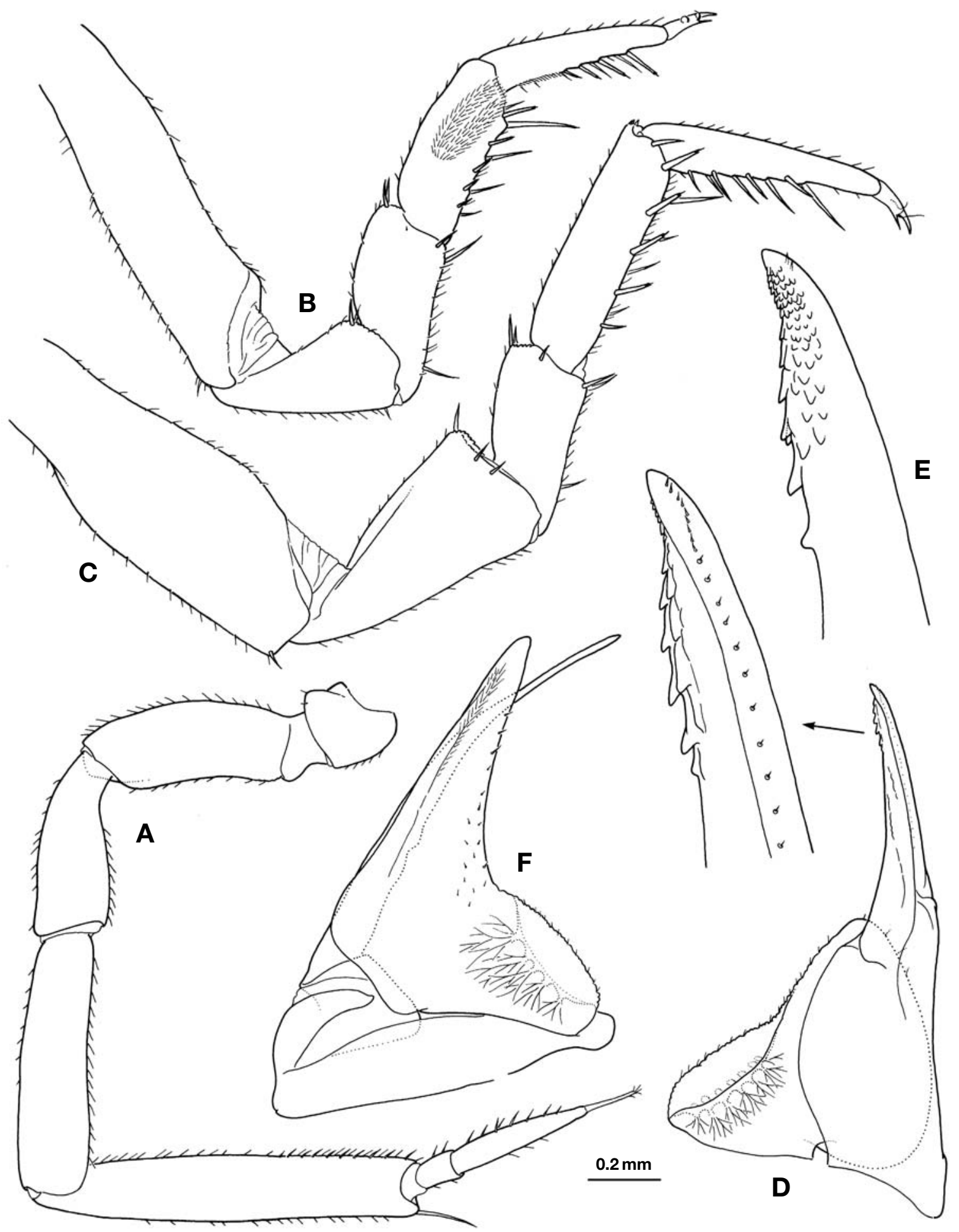

Fig. 3. Nesodillo kimi sp. nov., paratype male: A, antenna; B, pereopod 1; C, pereopod 7; D, pleopod 1; E, distal part of pleopod 1 endopod, rostral surface; $F$, pleopod 2.

obliquely directed exopod inserted on dorsal surface of protopod, beneath an oblique protuberance; endopod about 0.8 times as long as protopod, with grooved outer margin and three stout apical setae. 


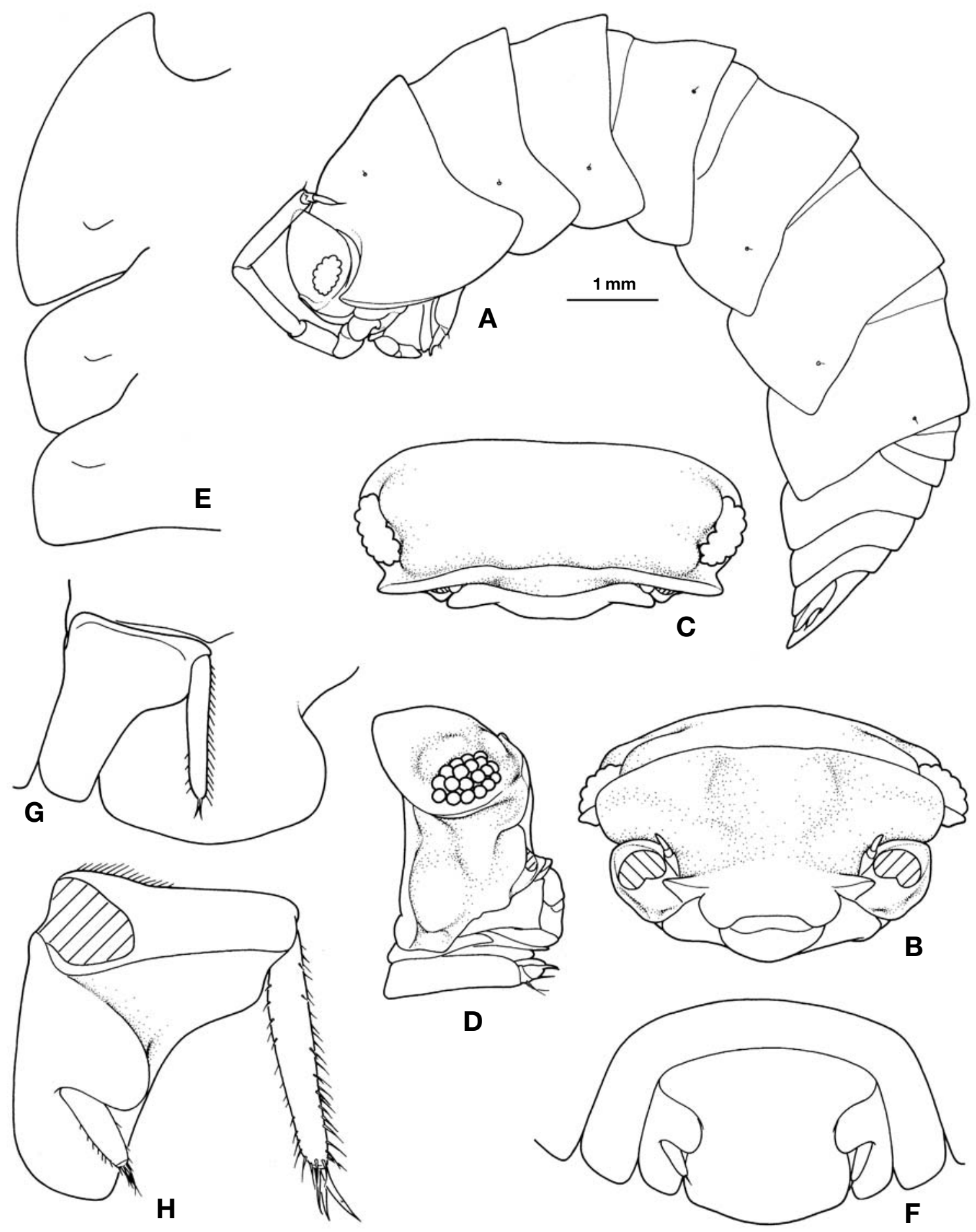

Fig. 4. Nesodillo philippinensis sp. nov., paratype female: A, habitus, lateral view; B, cephalon, frontal view; C, cephalon, dorsal view; $D$, cephalon, lateral view; $E$, pereonal epimera 1-3, ventral view; F, pleonites 4-5, telson and uropods, dorsal view; G, pleonal epimeron 5, telson and right uropod, ventral view; $\mathrm{H}$, left uropod, dorsal view.

Male. Pereopods without apparent sexual modification. Pleopod 1 exopod triangular, almost as long as wide; endopod with apical part bearing sharp denticles on lateral margin and numerous tiny ones on rostral surface. Pleopod 2 exopod 


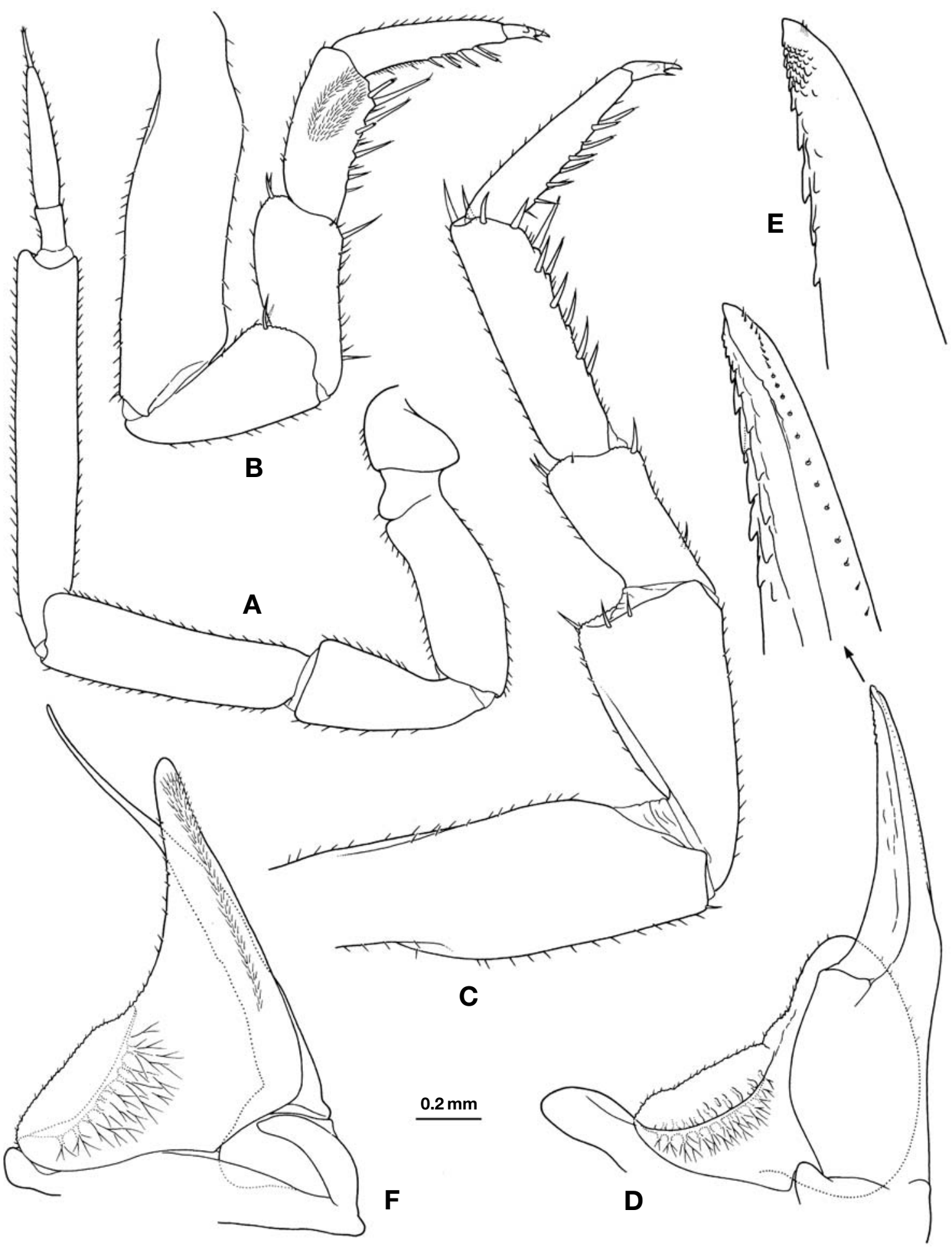

Fig. 5. Nesodillo philippinensis sp. nov., paratype male: A, antenna; B, pereopod 1 ; C, pereopod 7; D, pleopod 1 ; E, distal part of pleopod 1 endopod, rostral surface; $F$, pleopod 2.

about 1.4 times as long as wide; endopod bent outwards, longer than exopod.
Etymology. The new species is named after Dr. H.S. Kim (an Emeritus Professor, Seoul National University). 
Remarks. For the frontal shield depressed and bent backwards in the middle of upper border, Nesodillo kimi, sp. nov. resembles $N$. monticola (Vandel, 1973) from New Guinea. This new species differs from $N$. monticola in lateral margin of frontal shield broadly rounded and male pleopod 1 exopod as long as wide.

\section{Nesodillo philippinensis sp. nov. (Figs. 4-5)}

Type material. Holotype: ठ্ , dimension $12.0 \times 5.1 \mathrm{~mm}$, Negros I., Negros Occidental, Mambucal, ca. $30 \mathrm{~km}$ SE of Bacolod, litter, 22.XII.1992, leg. D.H. Kwon and D.S. Jeon (NBR). Paratypes: $8 \sigma^{\nearrow}$ ๙ 15 우우, same data as holotype (NBR); 8 ఠ $\sigma^{\nearrow}, 16$ 우 우, same data (IJB).

Non-type material examined. $7 \sigma^{\nearrow} \sigma^{\nearrow}, 8$ 우 우, 2 juvs., Cebu I., Cebu, Naga, Ulinga, Gawaygaway, 9.II.1997, leg. D.H. Kwon and J.A. Kim (IJB).

Description. Maximum dimension of male $12.0 \times 5.1 \mathrm{~mm}$, of female $11.8 \times 5.0 \mathrm{~mm}$. Color in alcohol dark brown with usual pale muscle spots; distal part of fifth article of antennal peduncle pigmentless; uropod light or yellowish brown. Dorsum smooth and covered with minute scale-spines. One nodulus lateralis per side on each pereonite; noduli laterales on pereonites 1, 4 and 7 much farther from lateral margins than ones on the other pereonites. Eye with 20-22 (18-20 in young specimens) ommatidia. Cephalon with frontal shield slightly protruding over vertex; profrons convex. Pereonal epimeron 1 thin and slightly bent outwards in anterior part; postero-lateral corner subacute and apex rounded; a small lobe on ventral surface. Each of pereonal epimera 2 and 3 quadrangular with a small lobe on ventral surface. Telson hour-glass shaped, with basal part wider than distal one, distal margin broadly rounded. Antenna with fifth article of peduncle about twice as long as flagellum; distal article of flagellum about three times as long as proximal one. Buccal pieces as in $N$. kimi, sp. nov. except for the left mandible with 4-5 penicils between molar penicil and lacinia mobilis. Pereopod 1 shortest of all; carpus shortest than any carpi of other pereopods, with a setose groove on rostral surface. Pereopods 2-7 similar in shape except for the shape of ischia with distal corners of tergal margins obtuse on pereopods 24 and right-angled on 5-7; posterior pereopods progressively longer. Each pleopodal exopod with a polyspiracular covered lung (Taiti et al., 1998). Uropodal protopod trapezoidal, fitting in the gap between pleonal epimeron 5 and telson, with mesial margin concave; obliquely directed exopod inserted on dorsal surface of protopod, beneath an oblique protuberance; endopod about 0.75 times as long as protopod, with grooved outer margin and three stout apical setae. Male. Pereopods without apparent sexual modifications. Pleopod 1 exopod almost as long as wide, with distal part slight- ly bent outwards; endopod with apical part bearing sharp denticles on lateral margin and tiny ones on rostral surface. Pleopod 2 exopod about 1.3 times as long as wide; endopod longer than exopod, with styliform distal part.

Etymology. The specific name refers to Philippines, where the material of this new species was collected.

Remarks. Nesodillo philippinensis, sp. nov. is very similar to $N$. kimi, sp. nov. It is distinguished from N. kimi by the shape of frontal shield not depressed in the middle of upper border, and of telson with broadly rounded distal margin (compare fig. 4 with fig. 1). The ventral lobes on pereonal epimera 1-3 of this new species are shorter than those of $N$. kimi, and the apical denticulated area on rostral surface of male pleopod 1 endopod is much smaller than that of $N$. kimi.

\section{ACKNOWLEDGEMENTS}

This work was supported by grant from Inje University, 2003.

\section{REFERENCES}

Arcangeli, A., 1927. Isopodi terrestri raccolti nell'Estremo Oriente dal Prof. Filippo Silvestri. Boll. Lab. Zool. Gen. Agr., 20: 211-269.

Budde-Lund, G., 1904. A revision of "Crustacea Isopoda terrestria" with additions and illustrations. 2. Spherilloninae. 3. Armadillo. Hagerup, Copenhagen, pp. 33-144, pls. 6-10.

Dollfus, A., 1890. Isopodes terrestres du "Challenger". Bull. Soc. Étud. Scient. Paris, 12(1889): 63-70, pls. 1-2.

Jeon, D.S. and D.H. Kwon, 2001. Two new species of the genus Filippinodillo (Isopoda, Oniscidea, Armadillidae) from Philippines. Korean J. Syst. Zool., 17: 155-164.

Schmalfuss, H., 1987. Filippinodillo maculatus nov. gen., nov. spec. (Isopoda, Armadillidae). Crustaceana, 53: 253-258.

Schmalfuss, H., 2003. World catalog of terrestrial isopods (Isopoda: Oniscidea). Stuttgarter Beitr. Naturk., Ser. A, (654): $1-341$.

Taiti, S., P. Paoli and F. Ferrara, 1998. Morphology, biogeography, and ecology of the family Armadillidae (Cruestacea, Oniscidea). Israel J. Zool., 44: 291-301.

Vandel, A., 1973. Les isopodes terrestres (Oniscoidea) de la Mélanésie. Zool. Verh., 125: 1-160.

Vandel, A., 1974. Une nouvelle espèce d'isopode terrestre (Isopoda, Oniscidea) provenant des Philippines: Sphaerilloides philippinensis n. sp. Crustaceana, 26: 61-64.

Verhoeff, K.W., 1926. Isopoda terrestria von Neu-Caledonien und den Loyalty-Inseln. In Sarasin \& Roux, eds., Nova Caledonia, Zoologie, 4: 243-366.

Received June 18, 2009 Accepted June 24, 2009 